\title{
Utilization of Microfiltration or Lactoperoxidase System or Both for Manufacture of Cheddar Cheese from Raw Milk ${ }^{1}$
}

\author{
Y. Amornkul and D. R. Henning ${ }^{2}$ \\ Alfred Chair Program, Dairy Science Department, South Dakota State University, Brookings 57007-0647
}

\begin{abstract}
The objective of the present study was to determine if application of microfiltration (MF) or raw milk lactoperoxidase system (LP) could reduce the risk of foodborne illness from Escherichia coli in raw milk cheeses, without adversely affecting the overall sensory acceptability of the cheeses. Escherichia coli K12 was added to raw milk to study its survival as a nonpathogenic surrogate organism for pathogenic $E$. coli. Five replications of 6 treatments of Cheddar cheese were manufactured. The 6 treatments included cheeses made from pasteurized milk (PM), raw milk (RM), raw milk inoculated with $E$. coli K12 (RME), raw milk inoculated with $E$. coli $\mathrm{K} 12+\mathrm{LP}$ activation (RMELP), raw milk inoculated with $E$. coli $\mathrm{K} 12+\mathrm{MF}$ (MFE), and raw milk inoculated with $E$. coli $\mathrm{K} 12+$ $\mathrm{MF}+\mathrm{LP}$ activation (MFELP). The population of $E$. coli $\mathrm{K} 12$ was enumerated in the cheese milks, in whey/ curds during cheese manufacture, and in final Cheddar cheeses during ripening. Application of LP, MF, and a combination of MF and LP led to an average percentage reduction of $E$. coli K12 counts in cheese milk by 72,88 , and $96 \%$, respectively. However, $E$. coli K12 populations significantly increased during the manufacture of Cheddar cheese for the reasons not related to contamination. The number of $E$. coli $\mathrm{K} 12$, however, decreased by 1.5 to $2 \log$ cycles during $120 \mathrm{~d}$ of ripening, irrespective of the treatments. The results suggest that MF with or without LP significantly lowers $E$. coli count in raw milk. Hence, if reactivation of $E$. coli during cheese making could be prevented, $\mathrm{MF}$ with or without LP would be an effective technique for reducing the counts of $E$. coli in raw milk cheeses. The cheeses were also analyzed for proteolysis, starter and nonstarter lactic acid bacteria (NSLAB), and sensory characteristics during ripening. The concentra-
\end{abstract}

Received April 13, 2007.

Accepted July 31, 2007.

${ }^{1}$ Published with the approval of the director of South Dakota Agricultural Experiment Station as publication 3566 of the Journal Series.

${ }^{2}$ Corresponding author: henning61@tds.net tion of $\mathrm{pH} 4.6$ soluble nitrogen at $120 \mathrm{~d}$ was greater in PM cheese compared with the other treatments. The level of $12 \%$ trichloroacetic acid-soluble nitrogen at $120 \mathrm{~d}$ was greater in RM, RME, and RMELP cheeses compared with PM, MFE, and MFELP cheeses. This could be related to the fact that cheeses made from raw milk with or without LP (RM, RME, and RMELP) had greater levels of NSLAB compared with PM, MFE, and MFELP cheeses. Cheeses at $60 \mathrm{~d}$, as evaluated by 8 trained panelists, did not differ in bitterness, pastiness, or curdiness attributes. Cheeses at $120 \mathrm{~d}$ showed no differences in acid-taste, bitterness, or curdiness attributes. Sensory analysis at $60 \mathrm{~d}$ showed that PM and MFELP cheeses had greater overall sensory acceptability than RM and RME cheeses. The overall sensory acceptability of the cheeses at $120 \mathrm{~d}$ showed that PM, MFE, and MFELP cheeses were more acceptable than RM and RME cheeses.

Key words: raw milk cheese, microfiltration, lactoperoxidase, Escherichia coli

\section{INTRODUCTION}

Microbiological safety is a major concern in the production of raw milk cheeses. Utilization of pasteurized milk to manufacture Cheddar cheese greatly reduces the microbiological risks associated with the consumption of cheese (Lochry et al., 1951). Hence, current standards for Cheddar cheese in United States require that cheese must be produced using pasteurized milk or, if cheese is made from unpasteurized milk, the cheese is required to be aged for $60 \mathrm{~d}$ or longer at a temperature not less than $1.7^{\circ} \mathrm{C}$ before distribution (Food and Drug Administration, 1994). The 60-d holding period was provided as an alternative to pasteurization based on the assumption that any pathogenic microorganisms in fresh cheese would be inactivated during this period. However, studies have shown that pathogens such as Escherichia coli O157:H7, Salmonella typhimurium, and Listeria monocytogenes can survive the minimum 60 -d curing period at a temperature not less than $1.7^{\circ} \mathrm{C}$ (Reitsma and Henning, 1996; Park et al., 1970; Ryser and Marth, 1987). Therefore, the current federal standards for $60 \mathrm{~d}$ of ripening of 
Cheddar cheese made from raw milk may not assure a safe product for consumers.

It has been reported that pasteurization can lead to several changes in cheese milk, including denaturation of whey proteins, interaction of whey proteins with caseins, inactivation of indigenous enzymes, as well as destruction of certain nonstarter lactic acid bacteria (McSweeney et al., 1993; Grappin and Beuvier, 1997). These changes in the cheese milk influence the sensory characteristics of the cheese manufactured from it (Johnson et al., 1990). Hence, cheese makers have been looking for alternative techniques that ensure the safety of cheese and maintain the desired sensory characteristics in cheese. Microfiltration (MF) and raw milk lactoperoxidase system (LP) are nonthermal methods that may reduce the risk of microbial pathogens in cheese.

Microfiltration is used in Canada and Europe to reduce the bacterial populations in milk before pasteurization but is not commonly practiced in the United States (Dairy Management Inc., 2001). When MF is used, it is necessary to separate fat from whole milk before $\mathrm{MF}$, because the fat globule diameter is greater than that of bacteria. Studies have shown that MF with the pore size of $1.4 \mu \mathrm{m}$ can be used to separate bacteria and spore-forming bacteria (such as Clostridium tyrobutyricum) from milk without the application of heat (Meershon, 1989; Mistry, 2002). A membrane pore size of $1.4 \mu \mathrm{m}$ leads to $>99 \%$ retention of bacteria and 99\% transmission of casein (Maubois, 1997). Although MF permeate contains a very low level of bacteria, it contains most of the casein and indigenous enzymes present in the original milk and is suitable for cheese making. Hence, utilization of MF has been suggested for cheese making (Kosikowski and Mistry, 1990; Saboya and Maubois, 2000; Neocleous et al., 2002 ), although it has not yet been utilized commercially.

Application of LP has been widely recognized for its antibacterial effect (Pruitt and Tenovuo, 1982; De Wit and Van Hooydonk, 1996). Ironically, the enzyme itself has no antibacterial effect on its own, and has to be activated to utilize the antibacterial function. Lactoperoxidase system present in raw milk is activated through the addition of sodium thiocyanate and sodium percarbonate (as a source of hydrogen peroxide) to the milk (International Dairy Federation, 1988). A reaction between thiocyanate $\left(\mathrm{SCN}^{-}\right)$and hydrogen peroxide $\left(\mathrm{H}_{2} \mathrm{O}_{2}\right)$ produces an antibacterial compound, hypothiocyanite ion $\left(\mathrm{OSCN}^{-}\right)$, which has a bacteriostatic effect on gram-positive bacteria and a bactericidal effect on gram-negative microorganisms (De Wit and Van Hooydonk, 1996; Kussendrager and Hooijdonk, 2000). According to Codex Alimentarius Com- mission (1991), LP is an approved method for raw milk preservation. An evaluation conducted by the Joint FAO/WHO Expert Committee on Food Additives concluded that when used according to their guidelines, LP does not present a toxicological hazard in milk (Codex Alimentarius Commission, 1991). The LP is promoted by FAO as an effective means of extending the shelf life of raw milk in developing countries where technical, economical, or practical reasons do not allow the use of cooling facilities for maintaining the quality of raw milk (FAO, 1999). However, utilization of LP is not approved for use in milk or milk products intended for the international market (FAO, 1999). This has led to a marketing concern among dairy manufacturers around the world. To respond to the concern and to provide scientific advice, $\mathrm{FAO} / \mathrm{WHO}$ has requested more information from industry and academia to evaluate the efficacy and safety of the use of LP for raw milk preservation and products derived from such preserved milk.

Hence, the objective of the present study was to determine if application of microfiltration or raw milk lactoperoxidase system or both could reduce the risk of foodborne illness from pathogenic Escherichia coli in Cheddar cheese manufacture from raw milk cheeses, without adversely affecting the overall sensory acceptability. In the present study, cheeses were manufactured in a university dairy pilot plant and thus, inoculation of milk using pathogens $(E$. coli $\mathrm{O} 157: \mathrm{H} 7)$ was not feasible. Hence, a nonpathogenic surrogate organism for E. coli O157:H7 was selected. Because MF separates microorganisms based on their size, nonpathogenic $E$. coli K12, which is similar in size to $E$. coli $\mathrm{O} 157: \mathrm{H} 7$, was identified as a suitable organism. In addition, $E$. coli $\mathrm{K} 12$ has been reported to exhibit a similar reduction as 0157:H7 when treated with LP in fruit and vegetable juice systems (Opstal et al., 2006). Hence, $E$. coli $\mathrm{K} 12$ was considered the best available surrogate for $E$. coli $\mathrm{O} 157: \mathrm{H} 7$ that could be added to raw milk to study its survival in cheese made from milk subjected to MF, LP, or a combination of both.

\section{MATERIALS AND METHODS}

\section{Experimental Design}

Five replicates of 6 treatments of Cheddar cheese were manufactured. Each replicate involved a different batch of raw whole milk as the starting material for the Cheddar cheese treatments. The experimental approach of cheese milk preparation and cheese manufacturing is shown in Figure 1. The 6 treatments included cheeses made from pasteurized milk (PM), raw milk (RM), raw milk inoculated with E. coli K12 


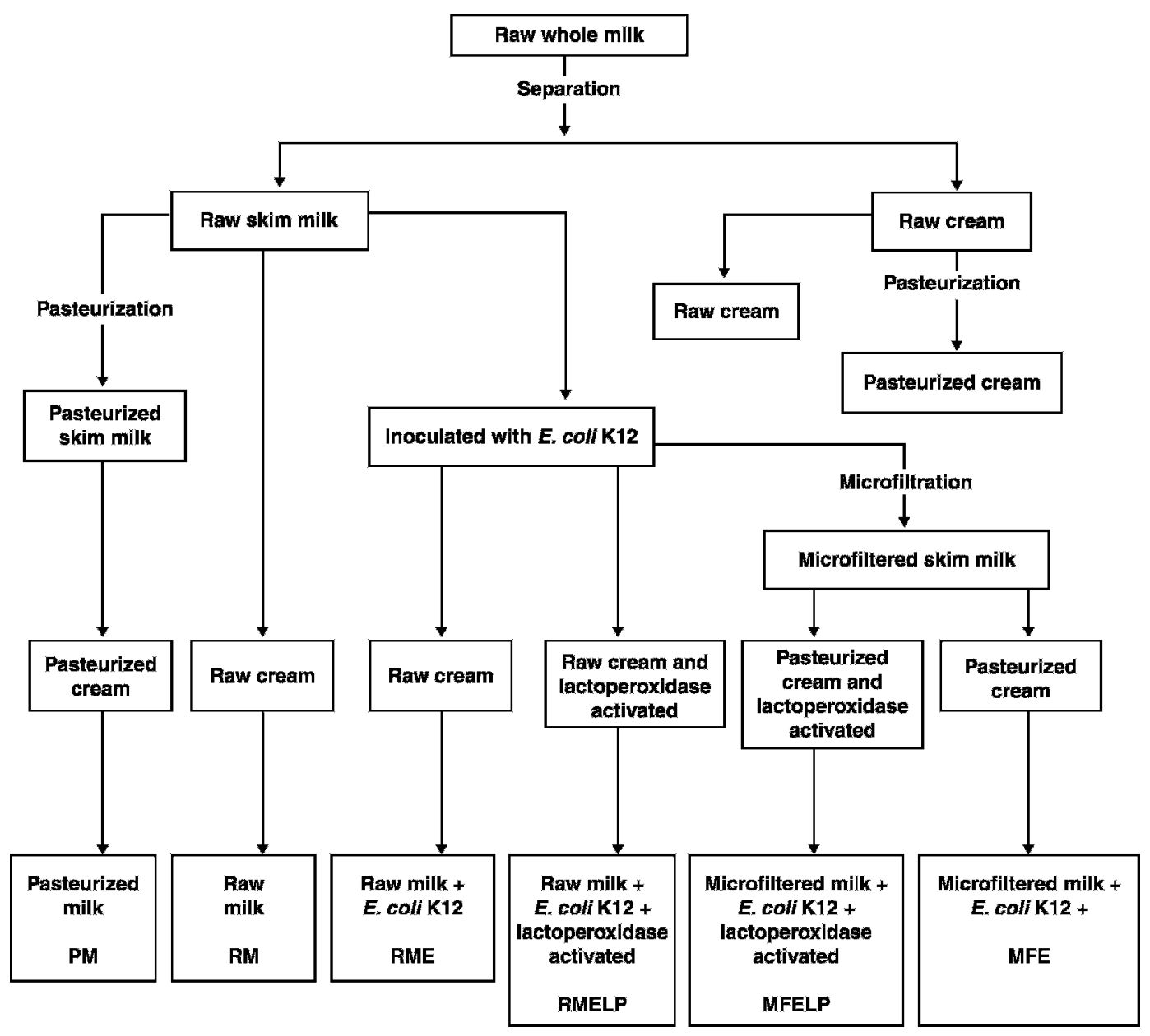

Figure 1. Experimental design for cheese milk preparation and cheese manufacture.

(RME), raw milk inoculated with $E$. coli $\mathrm{K} 12+\mathrm{LP}$ activation (RMELP), raw milk inoculated with $E$. coli K12 + microfiltration (MFE), and raw milk inoculated with $E$. coli $\mathrm{K} 12$ + microfiltration + LP (MFELP). Cheese manufacturing for each replicate was conducted over $3 \mathrm{~d}$, with 2 randomly selected treatments manufactured each day. Each replicate was completed within $5 \mathrm{~d}$ after the procurement of the raw whole milk.

\section{Preparation of Escherichia coli K12 Inoculum}

Escherichia coli K12 (ATCC 23716) was maintained on nutrient agar slants (Difco, Becton Dickinson Company, Sparks, MD). The culture was propagated in 10$\mathrm{mL}$ quantities of tryptic soy broth (Difco) at $37^{\circ} \mathrm{C}$ for 12 to $14 \mathrm{~h}$. A growth curve of $E$. coli K 12 populations corresponding to the absorbance at $650 \mathrm{~nm}$ of the culture was plotted. By using the growth curve, an inoculum sufficient to yield $100 \mathrm{cfu} / \mathrm{mL}$ in the cheese milk was prepared.

\section{Determination of Lactoperoxidase Enzyme Activity}

Raw skim milk for each replicate was collected to determine lactoperoxidase enzyme activity before the processing of cheese milk. The LP activity of the milk samples was measured using the ABTS [diammonium salt of 2,2'-azinodi (3-ethylbenzothiazoline-6-sulfonic acid)] assay (Pruitt et al., 1990). The assay was performed by mixing $10 \mu \mathrm{L}$ of milk and $2 \mathrm{~mL}$ of $1 \mathrm{mM}$ ABTS (Sigma Chemical Co., St. Louis, MO) in $0.1 M$ phosphate buffer $(\mathrm{pH}$ 6.0) in a cuvette. The reaction was initiated by adding $1 \mathrm{~mL}$ of $0.3 \mathrm{~m} M$ hydrogen peroxide (Sigma Chemical Co.) to the cuvette. The change in the absorbance readings at $412 \mathrm{~nm}$ for 60 $\mathrm{s}$ at 15-s intervals using the kinetics/time program (Beckman spectrophotometer DU 70, Beckman Instrument Inc., Fullerton, CA) at $25^{\circ} \mathrm{C}$ was recorded. The enzyme concentration was calculated from the rates generated by the kinetics/time program per minute using the formula according to Pruitt et al. (1990) and expressed in micrograms per milliliter of milk. 


\section{Preparation of Cheese Milk}

Raw whole milk was obtained from the South Dakota State University Dairy Research and Training Facility. Raw whole milk was passed through a cold $\left(4^{\circ} \mathrm{C}\right)$ separator (model 392, Separator Inc., Indianapolis, IN) and separated into cream and skim milk. One half of the raw cream was pasteurized $\left(66^{\circ} \mathrm{C}\right.$ for 30 min) in 37.85-L stainless steel cans in a chest tank (Meyer Blanke Company, St. Louis, MO), cooled to less than $15^{\circ} \mathrm{C}$, and stored at $4^{\circ} \mathrm{C}$ until used. The remainder of the raw cream was kept at $4^{\circ} \mathrm{C}$ until used. All 6 treatments of cheese milk were made from the same raw milk for each replication. The cheese milks for each treatment were prepared approximately $14 \mathrm{~h}$ before the time of cheese manufacturing.

Raw skim milk ( $818 \mathrm{~kg}$ ) was divided into 3 portions $(136,272$, and $409 \mathrm{~kg})$. The first part $(136 \mathrm{~kg})$ of the raw skim milk was pasteurized at $63^{\circ} \mathrm{C}$ for $30 \mathrm{~min}$, and the pasteurized cream was blended to obtain a casein:fat ratio of 0.7 . The Cheddar cheese made using this cheese milk was referred to as PM.

The second part ( $272 \mathrm{~kg}$ ) of raw skim milk was inoculated with $E$. coli $\mathrm{K} 12$ at a rate of $100 \mathrm{cfu} / \mathrm{mL}$, approximately $14 \mathrm{~h}$ before processing through the microfiltration unit $\left(1.7-\mathrm{m}^{2}\right.$ ceramic membrane, Techniques Industrielles Appliquees, Bollene, France). The 1.4- $\mu \mathrm{m}$ pore size ceramic membrane with a uniform transmembrane pressure system was operated in a temperature range of 36 to $42^{\circ} \mathrm{C}$, and the transmembrane pressure was approximately 0.25 bar. The flow rate of the skim milk was adjusted to $850 \mathrm{~L} / \mathrm{h}$. Pasteurized cream was blended with MF permeate to obtain cheese milk with the desired casein:fat ratio. The cheese milk obtained was divided into 2 equal parts: one half (136 $\mathrm{kg}$ ) of MF permeate cheese milk was used to make Cheddar cheese. This treatment was referred to as MFE. In the other half $(136 \mathrm{~kg})$ of MF permeate cheese milk, the LP was activated by adding $14 \mathrm{mg}$ of sodium thiocyanate (Sigma Chemical Co.), and $30 \mathrm{mg}$ of sodium percarbonate (Sigma Chemical Co.) per liter of milk (International Dairy Federation, 1988) approximately $14 \mathrm{~h}$ before Cheddar cheese making. This treatment was referred to as MFELP.

From the last portion ( $409 \mathrm{~kg}$ ) of the raw skim milk, $136 \mathrm{~kg}$ was removed and blended with raw cream to get the cheese milk with desired casein:fat ratio. The Cheddar cheese made using this cheese milk was referred to as RM. The remaining portion $(272 \mathrm{~kg})$ of the raw skim milk was blended with raw cream to get the cheese milk with the desired casein:fat ratio and was inoculated with $E$. coli $\mathrm{K} 12$ at a rate of $100 \mathrm{cfu} / \mathrm{mL}$. The first part $(136 \mathrm{~kg})$ of the inoculated raw cheese milk was used for the Cheddar cheese treatment re- ferred to as RME. The final portion $(136 \mathrm{~kg})$ of the cheese milk was activated with LP by adding $14 \mathrm{mg}$ of sodium thiocyanate (Sigma Chemical Co.) and 30 $\mathrm{mg}$ of sodium percarbonate (Sigma Chemical Co.) per liter of milk (International Dairy Federation, 1988) approximately $14 \mathrm{~h}$ before cheese making. This treatment was referred to as RMELP.

\section{Manufacture of Cheddar Cheese}

Five replicates of 6 treatments of Cheddar cheeses were manufactured. Each of 2 cheese vats ( $4 \mathrm{MX}$ model 65, Kusel Equipment Co., Watertown, WI) held 118 $\mathrm{kg}$ of cheese milk that was adjusted to a temperature of $32^{\circ} \mathrm{C}$. Calcium chloride solution (Danisco Food Ingredients, Madison, WI) was added at a rate of 0.2 $\mathrm{mL} / \mathrm{kg}$ of milk, followed by the mesophilic starter culture (bulk starter culture). The bulk starter culture was prepared using freeze-dried culture MA 019 (Dairy Connection Inc., Madison, WI) at a rate of 0.45 $\mathrm{g} / 100 \mathrm{~mL}$ in a Biolac $\mathrm{pH}$ complete medium $(7.5 \mathrm{~g} / 100$ $\mathrm{mL}$ of water, heated at $90^{\circ} \mathrm{C}$ for $45 \mathrm{~min}$, and cooled to room temperature; Rhodia Inc., Madison, WI), which was then incubated at $25^{\circ} \mathrm{C}$ for $14 \mathrm{~h}$. The rate of the starter addition into the cheese milk was $0.9 \%$ for treatments without LP activation and $1.4 \%$ for treatments with LP activation. Cheese milk with LP activated showed that LP inhibited the starter activity in preliminary trials, and hence had greater inoculum levels. After 60 min of ripening, double-strength rennet (Chymax, Chr. Hansen Inc., Milwaukee, WI) was added at a rate of $0.1 \mathrm{~mL} / \mathrm{kg}$ of milk. The coagulum was cut 25 to $30 \mathrm{~min}$ after the addition of rennet using 0.64-cm wire knives. The curds were left undisturbed for $15 \mathrm{~min}$. The curds and whey were heated to $38^{\circ} \mathrm{C}$ in 30 min with gentle stirring and then held at $38^{\circ} \mathrm{C}$ for $30 \mathrm{~min}$. Whey was drained, and the curds were cheddared until the curds $\mathrm{pH}$ reached 5.4. The curds were then milled and salted with dry food-grade salt at $2.7 \%$ by weight of the starting cheese milk. The salted curds were hooped and pressed overnight (14 h) at $2.8 \mathrm{~kg} / \mathrm{cm}^{2}$ (AFVS-Spec, Kusel Equipment Co.). The pressed cheese blocks $(9.1 \mathrm{~kg})$ were subsequently vacuum-packaged (Simpromac, Concord, Ontario, Canada) and stored at $4^{\circ} \mathrm{C}$ for ripening.

\section{Sample Collection}

Milk, Whey, and Curd Samples. Milk, whey, and curd samples were collected in sterile plastic snap-lid vials. Skim milk and cream were collected for $E$. coli K12 enumeration and compositional analyses. Microfiltered permeate and retentate samples were collected for $E$. coli $\mathrm{K} 12$ enumeration. All cheese milk 
samples were collected for microbiological and compositional analyses. Whey and unsalted curd samples were collected for $E$. coli K12 enumeration during cheese manufacture.

Cheese Samples. Cheeses samples at d 1 were taken by using a cheese trier to pull a sample from the 9.1-kg blocks of each treatment. On d 14 of ripening, the 9.1-kg blocks of cheese were cut into smaller subsamples (approximately $100-\mathrm{g}$ portions), vacuum packaged, sealed in clear Cryovac bags (Cryovac Division, W.R. Grace and Co., Duncan, SC) for ease of analysis at each curing interval, and stored at $4^{\circ} \mathrm{C}$ for ripening. Packages of cheeses subsamples were randomly taken for analyses at different ripening times $(14,30,60,90$, and 120 d). For microbiological analysis, cheeses were aseptically cut into small pieces and transferred into a sterile bag. The remainder of each sample was ground in a blender (Osterizer Galaxie, Sunbeam Products, Inc., Boca Raton, FL), packed into a $50-\mathrm{mL}$ plastic snap-lid vial, and stored at $-20^{\circ} \mathrm{C}$ until analyzed for $\mathrm{pH}$ and other compositional analyses.

Compositional Analysis. Skim milk and cream samples were analyzed for total protein using the Kjeldahl method (method 920.123; AOAC, 2000) and fat using the Mojonnier method (Atherton and Newlander, 1977). These results were used to standardize cheese milk to the desired casein:fat ratio. Cheese samples $14 \mathrm{~d}$ after manufacture were used for compositional analysis. The convection oven method (method 926.08; AOAC, 2000) was used to analyze the moisture content of the cheeses. Total protein content of the cheeses was determined by measuring the total $\mathrm{N}$ in the cheese using the Kjeldahl method (method 920.123; AOAC, 2000) and converting it to protein using a factor of 6.38. The fat content of the cheese was determined using the Mojonnier method (Atherton and Newlander, 1977). The salt content of the cheese was determined using a chloride analyzer (model 926, Nelson Jameson Inc., Marshfield, WI). The ash content of the cheese was determined using the muffle furnace method (method 935.43; AOAC, 2000). The pH of milk, whey, and cheese curds during manufacturing and cheeses during ripening was measured using a combination $\mathrm{pH}$ electrode (Accumet accuCap gel-filled, Fisher Scientific, Pittsburgh, PA) and $\mathrm{pH}$ meter (model 340, Corning, Inc., Corning, NY). Cheese samples at $1,14,30,60,90$, and $120 \mathrm{~d}$ of ripening were prepared for $\mathrm{pH}$ measurement by compacting $20 \mathrm{~g}$ of ground cheese in a plastic snap-lid vial and adding $5 \mathrm{~g}$ of deionized water (Upreti et al., 2004).

Microbiological Analyses. Milk and whey samples were thoroughly mixed before diluting and plating. Eleven grams of unsalted curds or cheese samples were obtained aseptically and homogenized for $2 \mathrm{~min}$ at high speed using a laboratory stomacher (Seward model 400, Seward, London, UK) with $99 \mathrm{~mL}$ of sterile $2 \%(\mathrm{wt} / \mathrm{wt})$ sodium citrate at $45^{\circ} \mathrm{C}$. Serial dilutions were prepared in phosphate dilution buffer, appropriate dilutions were added to sterile Petri dishes, and appropriate molten agar added.

Escherichia coli K12. Enumeration of E. coli K12 was performed as described in Richardson (1985). Escherichia coli K12 populations in all samples were determined using violet red bile agar (VRBA) with 4-methylumbelliferyl- $\beta$-D-glucuronide (MUG) (Difco); MUG is a substrate used to detect glucuronidase activity. Escherichia coli produce the enzyme glucuronidase, which hydrolyzes MUG to yield a fluorogenic compound detectable with UV light at $366 \mathrm{~nm}$. Typical strains of $E$. coli form red colonies surrounded by bile precipitate and exhibit blue fluorescence on VRBA with MUG. Typical fluorescing colonies were occasionally confirmed by API E 20 diagnostic kit (bioMerieux Vitek Inc., St. Louis, MO) as E. coli.

Starter and Nonstarter Lactic Acid Bacteria. The method for enumerating the starter and nonstarter lactic acid bacteria (NSLAB) populations was performed as described in Richardson (1985). The starter populations in all samples were determined by using M17 agar (Difco) after incubation at $32^{\circ} \mathrm{C}$ for 48 $\mathrm{h}$ under a reduced oxygen concentration (BBL GasPak Anaerobic System, Difco; or Mitsubishi Gas Chemical America, Inc., New York, NY). Nonstarter lactic acid bacteria populations were determined by using acidified ( $\mathrm{pH}$ 5.4) lactobacilli MRS agar (Difco) after incubation at $32^{\circ} \mathrm{C}$ for $48 \mathrm{~h}$.

\section{Evaluation of Proteolysis}

Proteolysis of cheese samples was analyzed at 1,60, and $120 \mathrm{~d}$ of ripening. Proteolysis was characterized by measuring $\mathrm{pH} 4.6$ and $12 \%$ TCA-soluble nitrogen (SN), and the results were expressed as $\mathrm{pH} 4.6$ and $12 \%$ TCA SN as a percentage of total nitrogen.

pH 4.6 SN. The pH 4.6 SN used sodium acetate and sodium chloride to determine a value for primary proteolysis in ripened cheese. The components in the $\mathrm{pH} 4.6$ solution set up conditions for intact casein to precipitate out of solution and allow large and small peptides to remain soluble in the solution. The $\mathrm{pH} 4.6$ $\mathrm{SN}$ in cheeses was analyzed using the method described by Bynum and Barbano (1985). Following this method, approximately $0.75 \mathrm{~g}$ of ground cheese was weighed into a 118-mL Whirl-Pak sample bag (Nelson Jameson Inc.) and mixed with $25 \mathrm{~mL}$ of pH 4.6 Sharp's solution (Bynum and Barbano, 1985). The cheese was homogenized for $2 \mathrm{~min}$ at high speed using a stomacher (Seward model 400). The cheese solution was trans- 
ferred to a 50-mL centrifuge tube (Nalge Company, Rochester, NY), and centrifuged at $3,000 \times g$ at $4^{\circ} \mathrm{C}$ for $10 \mathrm{~min}$ (Sorvall RC5C Refrigerated Centrifuge, Dupont Instruments, Wilmington, DE). The extract was filtered through Whatman \#2 filter paper (Whatman International Ltd., Maidstone, UK), and the filtrate was analyzed using the Kjeldahl procedure for total nitrogen (method 920.123; AOAC, 2000).

$12 \%$ TCA SN. The $12 \%$ TCA SN was used to measure secondary proteolysis in ripened cheese. Trichloroacetic acid solution destabilizes large peptides and proteins and causes them to precipitate, but allows the small peptides to remain in solution. The $12 \%$ TCA SN in cheeses was analyzed using the method described by Christensen et al. (1991). Using this method, approximately $1.5 \mathrm{~g}$ of ground cheese was weighed in a 118-mL Whirl-Pak sample bag (Nelson Jameson Inc.), and mixed with $25 \mathrm{~mL}$ of $12 \%$ TCA solution. The cheese was homogenized for $2 \mathrm{~min}$ at high speed using a stomacher (Seward model 400). The cheese solution was transferred to a $50-\mathrm{mL}$ centrifuge tube (Nalge Company), and centrifuged at 3,000 $\times \mathrm{g}$ at $4^{\circ} \mathrm{C}$ for $10 \mathrm{~min}$ (Sorvall RC5C Refrigerated Centrifuge, Dupont Instruments). The extract was filtered through Whatman \#2 filter paper (Whatman International Ltd.), and the filtrate was used for Kjeldahl analysis (method 920.123; AOAC, 2000).

\section{Sensory Evaluation}

The cheese samples were evaluated for sensory characteristics at 60 and $120 \mathrm{~d}$. The cheese samples were judged by 8 trained panelists. Because 5 of the cheese samples were made from unpasteurized milk, 4 of the cheese samples were inoculated with the $E$. coli K12 in each replication, and 2 of the cheeses were made from LP-activated milk (which added $14 \mathrm{mg}$ of sodium thiocyanate and $30 \mathrm{mg}$ of sodium percarbonate per liter of milk), approval from the South Dakota State University Human Subject Committee was obtained (University Approval No. 050310). The 8 panelists were informed that $E$. coli $\mathrm{K} 12$ is considered a nonpathogenic organism by the National Institutes of Health and given information from WHO that supports the safety of LP activation in milk. Additionally, the cheese samples were analyzed by the visual immunoprecipitate assay (BioControl Systems Inc., Bellevue, WA) for the detection of E. coli O157:H7, Salmonella spp., and Listeria spp. to ensure these organisms were absent.

The sensory study evaluated the following: flavor (acid, bitter, unclean, sulfide, and overall flavor), body and texture (firmness, pastiness, meanliness, crumbliness, curdiness, shortness, and overall body and tex- ture), and overall appearance and acceptability. The cheese samples were cut into pieces (about $3 \times 8 \mathrm{~cm}^{2}$ ). Each treatment of the cheese samples was labeled using random 3-digit numbers and presented to the panelists in identical containers for evaluation. The scale for flavor, body, and texture defect attributes was $1=$ none, $5=$ definite, and $9=$ pronounced. The scale for overall flavor, body and texture, appearance, and acceptability attributes was $1=$ poor, 5 = average, and $9=$ excellent. The scores were recorded and compared among the panelists.

\section{Statistical Analyses}

Randomized complete block design with the 6 Cheddar cheese treatments was used for statistical analysis. The 5 replicates were treated as the blocks of the design. Analysis of variance was used for evaluating the difference between treatments. Changes in $\mathrm{pH}, E$. coli $\mathrm{K} 12$, starter and NSLAB counts, $\mathrm{pH} 4.6 \mathrm{SN}$, and $12 \%$ TCA SN during ripening were analyzed by using a repeated measures design. The GLM procedure of SAS was used for all data analyses (SAS Institute, 1999). Means were compared using Fisher's least significant different (LSD) procedure. Comparisons were made at the 0.05 level of significance and the results were considered significant at $P<0.05$.

\section{RESULTS AND DISCUSSION}

\section{Cheese Milk Composition}

The cheese milks were prepared by mixing skim milk (raw, pasteurized, or microfiltered) and cream (raw or pasteurized; Figure 1). The average fat contents of skim milk and cream were $0.13 \%( \pm 0.05)$ and $35.26 \%$ ( \pm 2.79$)$. The average protein contents of skim milk and cream were $3.29 \%( \pm 0.08)$ and $2.13 \%( \pm 0.09)$. The MF skim milk had fat and protein contents of $0.05 \%( \pm 0.02)$ and $3.17 \%( \pm 0.12)$, respectively. Lactoperoxidase enzyme concentration was measured in raw skim milk to confirm the concentration of the enzyme in the milk; the average level in raw skim milk was $27.8 \pm 6.72 \mu \mathrm{g} / \mathrm{mL}$. This was similar to the level indicated by De Wit and Van Hooydonk (1996). Average cheese milk composition for all the treatments is given in Table 1. The protein content in the cheese milks was similar, whereas the fat content was different ( $P$ $<0.05$ ) among the treatments. Consequently, it led to differences in casein:fat ratio during preparation, which ranged from 0.67 to 0.73 for the 6 treatments. Moreover, the $\mathrm{pH}$ was different $(P<0.05)$ among the treatments and ranged from 6.59 to 6.67. 
Table 1. Average composition of cheese milk used for manufacture cheeses of different treatments (mean of 5 replicates)

\begin{tabular}{lllllllll}
\hline & \multicolumn{7}{c}{ Treatment $^{1}$} \\
Parameter & PM & RM & MFE & MFELP & RME & RMELP & SEM & $R^{2}$ \\
\hline Fat, \% & $3.41^{\mathrm{c}}$ & $3.51^{\mathrm{bc}}$ & $3.55^{\mathrm{ab}}$ & $3.57^{\mathrm{ab}}$ & $3.52^{\mathrm{bc}}$ & $3.65^{\mathrm{a}}$ & 0.04 & 0.85 \\
Total protein, \% & 3.17 & 3.24 & 3.07 & 3.15 & 3.15 & 3.14 & 0.02 & 0.76 \\
Casein, $^{2} \%$ & 2.47 & 2.52 & 2.40 & 2.46 & 2.46 & 2.45 & 0.02 & 0.76 \\
Casein:fat ratio & $0.73^{\mathrm{a}}$ & $0.72^{\mathrm{ab}}$ & $0.68^{\mathrm{c}}$ & $0.69^{\mathrm{bc}}$ & $0.70^{\mathrm{abc}}$ & $0.67^{\mathrm{c}}$ & 0.01 & 0.64 \\
pH & $6.59^{\mathrm{b}}$ & $6.65^{\mathrm{ab}}$ & $6.65^{\mathrm{ab}}$ & $6.65^{\mathrm{ab}}$ & $6.67^{\mathrm{a}}$ & $6.64^{\mathrm{ab}}$ & 0.01 & 0.45 \\
\hline
\end{tabular}

${ }^{a-c}$ Means in a row with the same superscript are not different; means with no superscripts are not significantly different $(P \geq 0.05)$.

${ }^{1} \mathrm{PM}=$ cheese made from pasteurized milk; $\mathrm{RM}$ = cheese made from raw milk; MFE = cheese made from raw milk inoculated with Escherichia coli $\mathrm{K} 12$ + microfiltration (MF); MFELP = cheese made from raw milk inoculated with $E$. coli $\mathrm{K} 12+\mathrm{MF}$ + lactoperoxidase system (LP) activation; RME = cheese made from raw milk inoculated with $E$. coli K12; RMELP = raw milk inoculated with $E$. coli $\mathrm{K} 12+\mathrm{LP}$ activation .

${ }^{2}$ Casein $=78 \%$ of total protein.

\section{Cheese Composition}

The average composition of the 6 Cheddar cheese treatments (PM, RM, MFE, MFELP, RME, and RMELP) is indicated in Table 2. The cheese samples were similar in ash and protein but differed $(P<0.05)$ in moisture, fat, salt, and $\mathrm{pH}$. The moisture content in cheeses ranged from 37.26 to $39.41 \%$. The moisture level of PM cheese was greater $(P<0.05)$ than RM, RME, RMELP, MFE, and MFELP cheeses. This is in accordance with the fact that cheeses made from pasteurized milk have been reported to have greater moisture than cheeses made from raw milk (Lochry et al., 1951).

The fat content in cheeses ranged from 31.96 to $34.77 \%$. The PM cheese had a lower $(P<0.05)$ fat content compared with other cheeses, which could be related to greater moisture in PM cheese. To determine if a lower level of fat in PM cheese was attributed to its greater moisture content, fat content was recalculated on a DM basis (Table 2). Comparison of fat in DM of PM cheese with other treatments indicated that it was not different $(P<0.05)$ from RM, RME, and RMELP cheeses but was different from MFE and MFELP cheeses (Table 2). This indicates that the lower fat content of PM cheese might not solely be due to its high moisture; in part, it may be due to the lower fat content of the cheese milk that was used to make PM cheeses (Table 1).

Salt content in the cheeses ranged from 1.39 to $1.74 \%$. Despite the fact that all the cheeses were salted at the same rate, the salt content in MFE cheeses was greater $(P<0.05)$ than in the rest of the treatments. This also led to a greater salt-to-moisture ratio in the MFE cheeses. Consequently, a greater $(P<0.05) \mathrm{pH}$ value at $14 \mathrm{~d}$ of ripening was observed for the MFE cheeses. A similar effect of salt-to-moisture ratio on

Table 2. Average composition of cheeses corresponding to different treatments (mean of 5 replicates)

\begin{tabular}{lcccccccr}
\hline & \multicolumn{7}{c}{ Treatment $^{1}$} \\
Parameter & PM & RM & MFE & MFEP & RME & RMELP & SEM & $R^{2}$ \\
\hline Moisture, \% & $39.41^{\mathrm{a}}$ & $37.69^{\mathrm{b}}$ & $37.61^{\mathrm{b}}$ & $38.41^{\mathrm{b}}$ & $37.26^{\mathrm{b}}$ & $37.35^{\mathrm{b}}$ & 0.23 & 0.50 \\
Fat, \% & $31.96^{\mathrm{b}}$ & $33.86^{\mathrm{a}}$ & $34.77^{\mathrm{a}}$ & $33.74^{\mathrm{a}}$ & $33.82^{\mathrm{a}}$ & $33.75^{\mathrm{a}}$ & 0.25 & 0.56 \\
Fat in DM, \% & $52.73^{\mathrm{c}}$ & $54.35^{\mathrm{abc}}$ & $55.72^{\mathrm{a}}$ & $54.78^{\mathrm{ab}}$ & $53.91^{\mathrm{bc}}$ & $53.88^{\mathrm{bc}}$ & 0.29 & 0.58 \\
Protein, \% & 24.63 & 24.80 & 24.64 & 24.16 & 24.95 & 25.11 & 0.20 & 0.58 \\
MNFS, \% & 57.91 & 57.00 & 57.66 & 57.96 & 56.31 & 56.38 & 0.13 & 0.51 \\
Salt, \% & $1.54^{\mathrm{b}}$ & $1.39^{\mathrm{b}}$ & $1.74^{\mathrm{a}}$ & $1.53^{\mathrm{b}}$ & $1.49^{\mathrm{b}}$ & $1.46^{\mathrm{b}}$ & 0.03 & 0.57 \\
Salt-to-moisture & $3.91^{\mathrm{b}}$ & $3.69^{\mathrm{b}}$ & $4.64^{\mathrm{a}}$ & $3.98^{\mathrm{b}}$ & $3.99^{\mathrm{b}}$ & $3.92^{\mathrm{b}}$ & 0.07 & 0.62 \\
Ash, \% & 3.54 & 3.49 & 3.54 & 3.49 & 3.55 & 3.48 & 0.03 & 0.15 \\
pH at 14 d & $4.94^{\mathrm{b}}$ & $4.94^{\mathrm{b}}$ & $5.04^{\mathrm{a}}$ & $4.96^{\mathrm{b}}$ & $4.91^{\mathrm{b}}$ & $4.92^{\mathrm{b}}$ & 0.01 & 0.72 \\
\hline
\end{tabular}

${ }^{\mathrm{a}-\mathrm{c}}$ Means in a row with common superscripts do not differ $(P \geq 0.05)$.

${ }^{1} \mathrm{PM}=$ cheese made from pasteurized milk; $\mathrm{RM}=$ cheese made from raw milk; $\mathrm{MFE}=$ cheese made from raw milk inoculated with Escherichia coli $\mathrm{K} 12$ + microfiltration (MF); MFELP = cheese made from raw milk inoculated with $E$. coli $\mathrm{K} 12+\mathrm{MF}+$ lactoperoxidase system (LP) activation; RME = cheese made from raw milk inoculated with $E$. coli $\mathrm{K} 12$; RMELP = raw milk inoculated with $E$. coli $\mathrm{K} 12+\mathrm{LP}$ activation.

${ }^{2} \mathrm{MNFS}=$ moisture in nonfat substance. 

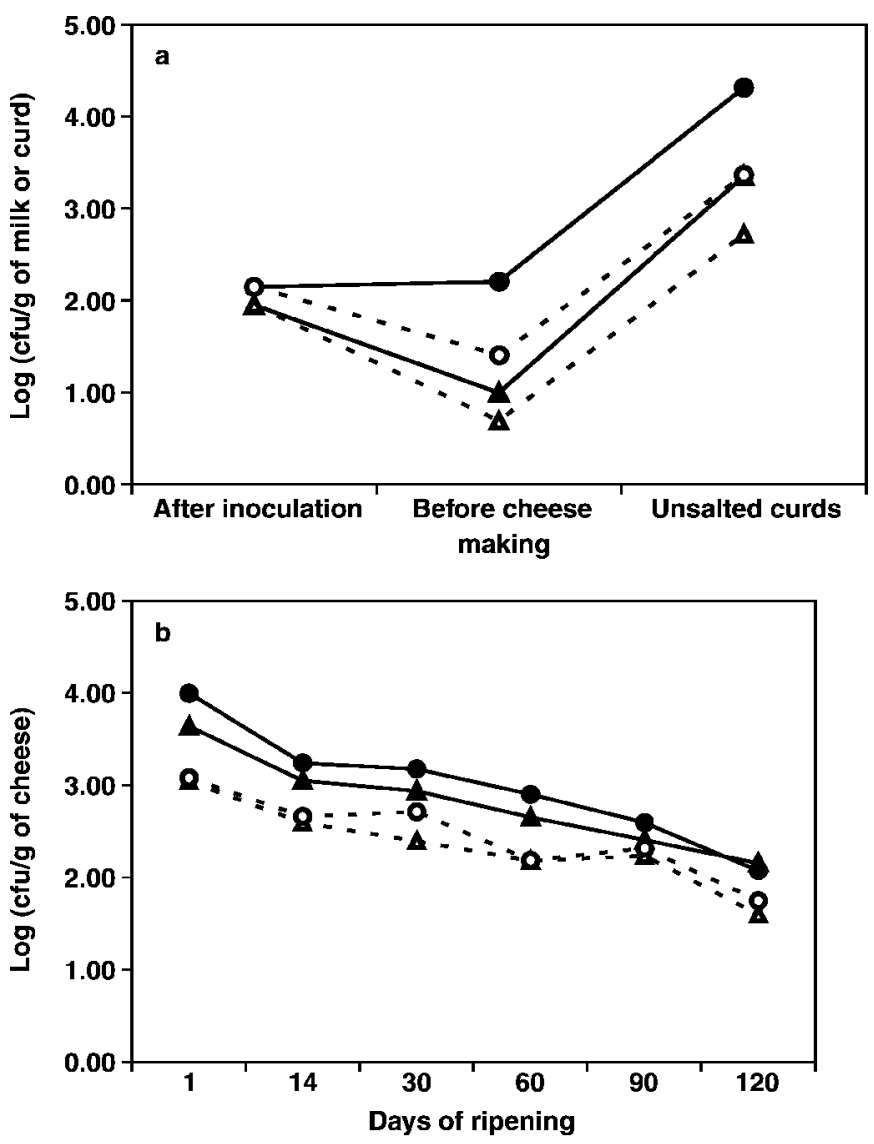

Figure 2. Changes in Escherichia coli K12 counts during a) cheese manufacture and b) cheese ripening. Curves: $-\mathbf{\Delta}-=\mathrm{MFE}$ (cheese made from raw milk inoculated with Escherichia coli K12 + microfiltration); --- $\triangle---=$ MFELP (cheese made from raw milk inoculated with E. coli $\mathrm{K} 12$ + microfiltration + lactoperoxidase system activation); - - = RME (cheese made from raw milk inoculated with $E$. coli K12); and ---O--- = RMELP (raw milk inoculated with E. coli $\mathrm{K} 12+$ lactoperoxidase system activation).

$\mathrm{pH}$ of cheese has been reported by other researchers (Schroeder et al., 1988; Pastorino et al., 2003).

\section{Effect of Treatments on E. coli K12}

Before Cheddar Cheese Manufacture. As shown in Figure 2a, $E$. coli K12 populations were lower $(P<$ 0.05 ) in cheese milks used to manufacture RMELP, MFE, and MFELP cheeses compared with the cheese milk used for RME cheese. The average percentage reduction of $E$. coli $\mathrm{K} 12$ populations in cheese milk (ratio of $E$. coli K12 counts after inoculation to before cheese making; Figure 2a) used for manufacturing RMELP, MFE, and MFELP cheeses was 72, 88, and $96 \%$, respectively. The percentage reductions of $E$. coli K12 populations in the cheese milks used for manufacturing MFE and MFELP cheeses were lower $(P<0.05)$ compared with the cheese milk used for RMELP cheese. This indicates that MF had a greater influence than LP on reducing $E$. coli K12 counts in cheese milk.

During Cheddar Cheese Manufacture. As shown in Figure 2a, the number of $E$. coli $\mathrm{K} 12$ in all treatments increased $(P<0.05)$ during the cheese-making process. The reasons for this are not presently known. The increase in $E$. coli $\mathrm{K} 12$ count might be suspected due to the contamination of milk or cheese curds during cheese manufacture and lack of specificity of the enumeration technique to detect a difference between $E$. coli $\mathrm{K} 12$ and other $E$. coli colonies. The VRBA-MUG agar is not specific for $E$. coli $\mathrm{K} 12$, but is only capable of differentiating an $E$. coli colony from other coliform colonies. However, our results for the ratio of $E$. coli counts in the cheese milk used for RM cheese (which did not have any inoculated $E$. coli K12) to $E$. coli counts in the cheese milk used for RME cheese (which was inoculated with $E$. coli K12) were in the range of 4 to $14 \%$ (data not shown). This indicates that the majority of the $E$. coli present in the milk were the inoculated $E$. coli K12. Hence, the colonies detected should be mostly $E$. coli K12, unless contamination occurred during cheese manufacturing. This possibility was overruled by the fact that the pasteurized milk, PM curds, and PM cheese did not show any $E$. coli (data not shown). If contamination were an issue, then the PM cheese would have shown higher counts of E. coli.

The information gathered in the present study does not allow us to identify the reason for the increase in E. coli K12 counts during cheese making. It could be speculated that the temperatures during cheese manufacturing were close to the optimum growth temperature of $E$. coli $\mathrm{K} 12\left(30\right.$ to $\left.35^{\circ} \mathrm{C}\right)$. In addition, E. coli $\mathrm{K} 12$ populations in the milk might become concentrated in the curd.

During Cheese Ripening. The counts of E. coli K12 during cheese ripening are shown in Figure 2b. There was a decrease $(P<0.05)$ in $E$. coli K12 populations in all the cheeses. In addition, no effect of treatments on $E$. coli $\mathrm{K} 12$ population in cheeses during ripening was observed. A similar decrease in $E$. coli K12 counts during ripening among the treatments indicated that the survival of $E$. coli $\mathrm{K} 12$ in cheese during ripening was related to the intrinsic characteristics of the cheese, such as $\mathrm{pH}$ and water activity, rather than the treatments given to the milk used for manufacturing cheese. Hence, it was inferred from the data that if cheese makers were able to lower the number of $E$. coli in the cheeses at $\mathrm{d} 1$, the number would decrease continuously during ripening, leading to undetectable levels at $60 \mathrm{~d}$ or earlier.

The results suggest that if cheese makers could decrease the number of $E$. coli in the cheese milk using 


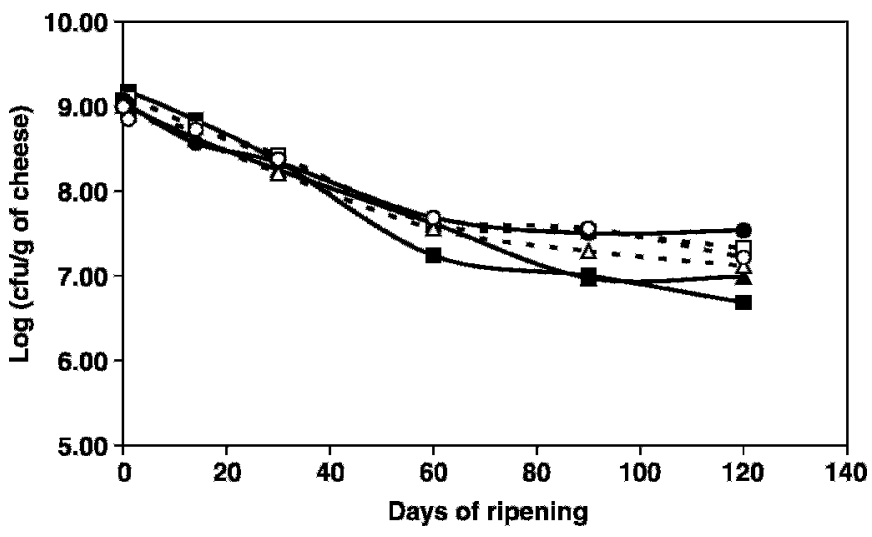

Figure 3. Changes in the population of starter lactic acid bacteria during $120 \mathrm{~d}$ of ripening. Curves: $-\boldsymbol{\square}-=\mathrm{PM}$ (cheese made from pasteurized milk); --- $\square---=$ RM (cheese made from raw milk); $-\mathbf{\Delta}-=$ MFE (cheese made from raw milk inoculated with Escherichia coli K12 + microfiltration); --- $\triangle---=$ MFELP (cheese made from raw milk inoculated with $E$. coli $\mathrm{K} 12$ + microfiltration + lactoperoxidase system activation); - - = RME (cheese made from raw milk inoculated with $E$. coli K12); and ---O--- = RMELP (raw milk inoculated with E. coli $\mathrm{K} 12$ + lactoperoxidase system activation).

either MF or an MF and LP combination, and could prevent its increase during cheese making, cheese makers would have ways of manufacturing safe, unpasteurized milk cheeses.

\section{Lactic Acid Bacteria During Cheese Ripening}

Starter Lactic Acid Bacteria. The changes in population of starter lactic acid bacteria during the 120 $d$ of ripening are shown in Figure 3 . The average population of starter bacteria in cheeses decreased $(P<$ $0.05)$ during cheese ripening from about $10^{9} \mathrm{cfu} / \mathrm{g}$ at d 1 to about $10^{7} \mathrm{cfu} / \mathrm{g}$ at $\mathrm{d} 120$. No difference was observed in the starter populations during cheese ripening among treatments. As mentioned earlier, the rate of starter addition was $0.9 \%$ for the cheeses made from milk without LP activation and $1.4 \%$ for the cheeses made from the milk with LP activation. However, there was no difference in the starter populations between the cheeses made from milk with LP activation and the cheeses made without it. This may be due to the bacteriostatic effect of LP on the starter populations during cheese making. Inhibition of the starter cultures by LP has also been reported by Zall et al. (1983) and Sarkar and Misra (1992). In addition, a constant decline in the population of starter bacteria during the ripening of cheeses is well known and can be attributed to the depletion of lactose, low $\mathrm{pH}$, and high salt concentration in the cheeses (Peterson and Marshall, 1990).

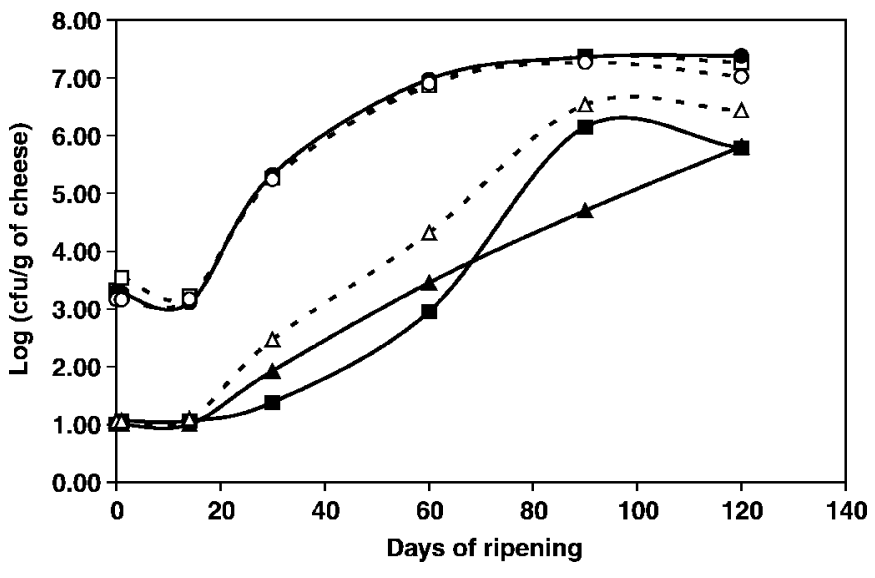

Figure 4. Changes in the population of nonstarter lactic acid bacteria during $120 \mathrm{~d}$ of ripening. Curves: $-\square-=\mathrm{PM}$ (cheese made from pasteurized milk); --- $\square---=$ RM (cheese made from raw milk); $-\boldsymbol{\Delta}-\mathbf{M}=\mathrm{MFE}$ (cheese made from raw milk inoculated with Escherichia coli $\mathrm{K} 12$ + microfiltration); --- $\triangle$--- $=$ MFELP (cheese made from raw milk inoculated with $E$. coli $\mathrm{K} 12$ + microfiltration + lactoperoxidase system activation); - - $=$ RME (cheese made from raw milk inoculated with $E$. coli $\mathrm{K} 12$ ); and ---O--- = RMELP (raw milk inoculated with $E$. coli $\mathrm{K} 12$ + lactoperoxidase system activation).

NSLAB. The change in population of NSLAB during the 120-d ripening period is shown in Figure 4. The NSLAB population increased $(P<0.05)$ during cheese ripening. The rate of increase and the total populations of NSLAB were influenced by the treatments of the cheese milk. The RM, RME, and RMELP cheeses had greater $(P<0.05)$ levels of NSLAB compared with PM, MFE, and MFELP cheeses. This can be attributed to the fact that pasteurization and microfiltration of milk may lead to a decrease in indigenous microflora of the raw milk. Many studies have demonstrated that the indigenous bacteria in milk play a major role in the development of flavor and texture characteristics in cheeses due to their role in secondary proteolysis during ripening (McSweeney et al., 1993; Fox and McSweeney, 1996; Grappin and Beuvier, 1997). In contrast with starter bacteria populations, NSLAB populations increased from lower counts to higher counts as the cheeses ripened. Because the starter populations among the treatments in the study were similar but NSLAB populations were different, the role of NSLAB in the secondary proteolysis may be expected.

\section{Change in pH During Cheese Ripening}

The changes in $\mathrm{pH}$ of all cheese samples at 1,14 , $30,60,90$, and $120 \mathrm{~d}$ of ripening are given in Figure 5 . There was decrease in $\mathrm{pH}$ during the first $30 \mathrm{~d}$ of ripening $(P<0.05)$. However, no difference in $\mathrm{pH}$ was found among the treatments during ripening. The final $\mathrm{pH}$ of the cheeses was lower than expected for Cheddar 


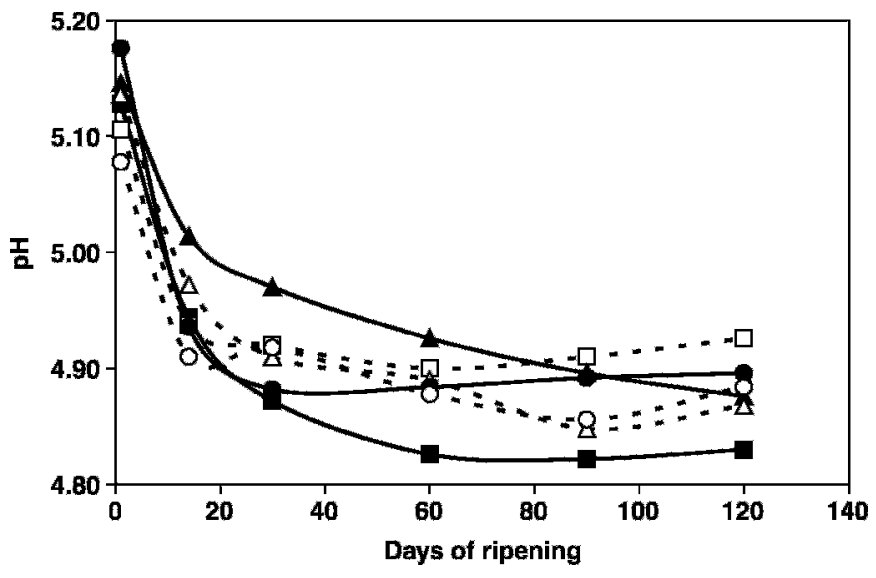

Figure 5. Changes in the $\mathrm{pH}$ during $120 \mathrm{~d}$ of ripening. Curves: - - - = PM (cheese made from pasteurized milk); --- $\square---=$ RM (cheese made from raw milk); $-\boldsymbol{\Delta}-=$ MFE (cheese made from raw milk inoculated with Escherichia coli $\mathrm{K} 12+$ microfiltration); --- $\triangle$--- = MFELP (cheese made from raw milk inoculated with E. coli $\mathrm{K} 12+$ microfiltration + lactoperoxidase system activation); $-0-=\mathrm{RME}$ (cheese made from raw milk inoculated with $E$. coli $\mathrm{K} 12$ ); and ---O--- = RMELP (raw milk inoculated with $E$. coli K12 + lactoperoxidase system activation).

cheeses and might have influenced proteolysis and sensory perception of the cheeses.

\section{Proteolysis in Cheeses During Ripening}

pH 4.6 SN. The changes in pH 4.6 SN expressed as a percentage of total nitrogen for all treatments during ripening are given in Figure 6. The content of $\mathrm{pH} 4.6$ $\mathrm{SN}$ of the cheese samples increased $(P<0.05)$ during

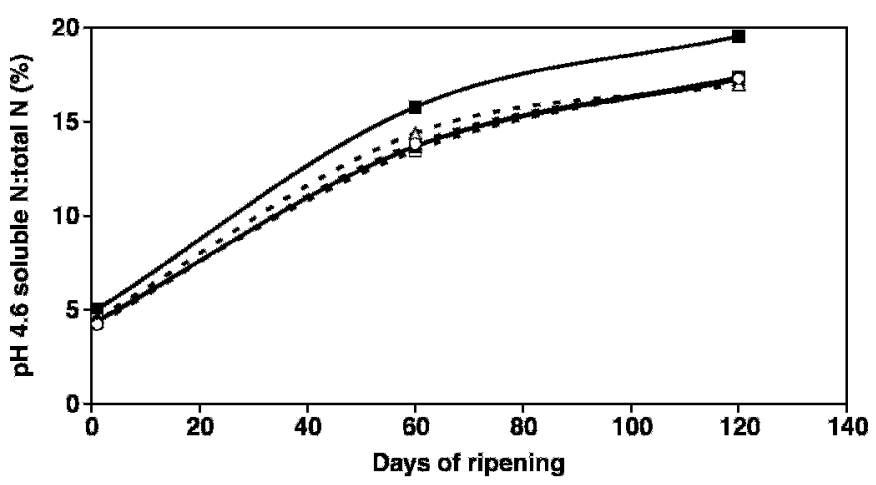

Figure 6. Changes in $\mathrm{pH} 4.6$ soluble nitrogen (expressed as \% total nitrogen) in the cheeses at 1,60 , and $120 \mathrm{~d}$ of ripening. Curves: - - - = PM (cheese made from pasteurized milk); --- $\square---=$ RM (cheese made from raw milk); $-\mathbf{\Delta}-=$ MFE (cheese made from raw milk inoculated with Escherichia coli $\mathrm{K} 12+$ microfiltration); --- $\triangle---=$ MFELP (cheese made from raw milk inoculated with $E$. coli $\mathrm{K} 12+$ microfiltration + lactoperoxidase system activation); $-0-=\mathrm{RME}$ (cheese made from raw milk inoculated with $E$. coli K12); and ---O--- = RMELP (raw milk inoculated with $E$. coli K12 + lactoperoxidase system activation).

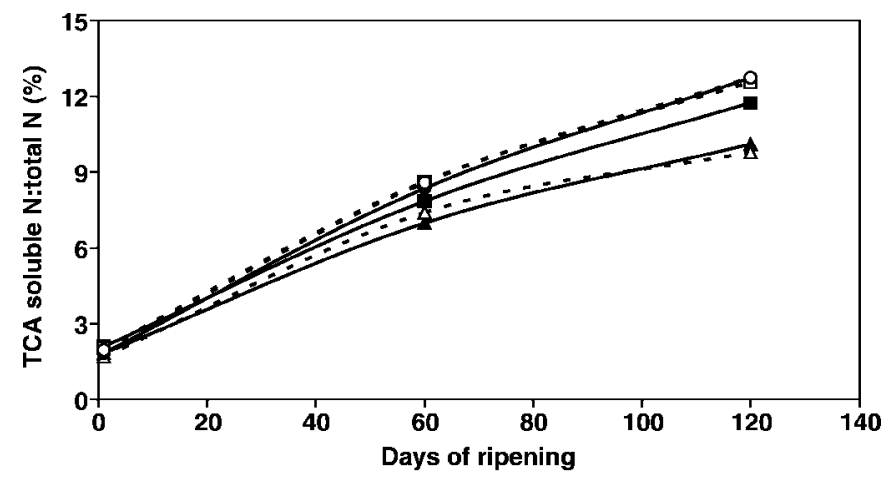

Figure 7. Changes in $12 \%$ TCA soluble nitrogen (expressed as \% total nitrogen) in the cheeses at 1,60 , and $120 \mathrm{~d}$ of ripening. Curves: - $-=$ PM (cheese made from pasteurized milk); --- $\square---=R M$ (cheese made from raw milk); $-\mathbf{\Delta}-=$ MFE (cheese made from raw milk inoculated with Escherichia coli $\mathrm{K} 12+$ microfiltration); --- $\triangle$--- = MFELP (cheese made from raw milk inoculated with $E$. coli $\mathrm{K} 12+$ microfiltration + lactoperoxidase system activation); $-\mathbf{0}-=\mathrm{RME}$ (cheese made from raw milk inoculated with $E$. coli K12); and ---O--- = RMELP (raw milk inoculated with $E$. coli K12 + lactoperoxidase system activation).

cheese ripening. The amount of $\mathrm{pH} 4.6 \mathrm{SN}$ at $120 \mathrm{~d}$ of ripening was higher $(P<0.05)$ in $\mathrm{PM}$ cheese compared with other treatments. However, the rate of increase in the concentration of $\mathrm{pH} 4.6 \mathrm{SN}$ during cheese ripening was similar among treatments. The $\mathrm{pH} 4.6 \mathrm{SN}$ measures the amount of casein that cannot be precipitated at $\mathrm{pH} 4.6$ (Sousa et al., 2001) and is an indicator of primary proteolysis during ripening. The $\mathrm{pH}$ 4.6-soluble peptides, in general, are formed due to protein hydrolysis by chymosin and pepsin. Pasteurization inactivates inhibitors of plasminogen activators. This may result in an increase of plasmin activity in the cheese milk, causing a greater level of primary proteolysis. In addition, as observed in this study, other studies have indicated that the water-soluble nitrogen level in the cheeses made from LP-activated milk is comparable to that in cheeses made from milk without LP activation (Atamer et al., 1999; Seifu et al., 2004).

$12 \%$ TCA SN. The changes in the percentage of $12 \%$ TCA SN expressed as a percentage of total nitrogen for all treatments during ripening are given in Figure 7. The level of $12 \%$ TCA SN in the cheese samples increased $(P<0.05)$ during ripening. All cheeses had similar level of $12 \%$ TCA SN at d 1, which increased at different $(P<0.05)$ rates during ripening. The rate of increase in $12 \%$ TCA SN was greater in RM, RME, and RMELP cheeses compared with PM, MFE, and MFELP cheeses. This led to a greater concentration of $12 \%$ TCA SN at $120 \mathrm{~d}$ of ripening in RM, RME, and RMELP cheeses compared with PM, MFE, and MFELP cheeses. However, no difference was observed 
Table 3. Sensory evaluation of the cheese samples at $60 \mathrm{~d}$

\begin{tabular}{lllllll}
\hline & \multicolumn{5}{c}{ Treatment $^{2}$} \\
\cline { 2 - 6 } Attribute $^{1}$ & PM & RM & MFE & MFELP & RME & RMELP \\
\hline Acid & $5.96^{\mathrm{ab}}$ & $6.04^{\mathrm{a}}$ & $5.33^{\mathrm{bc}}$ & $5.21^{\mathrm{c}}$ & $5.58^{\mathrm{abc}}$ & $5.86^{\mathrm{abc}}$ \\
Bitter & 3.08 & 2.83 & 3.29 & 2.88 & 3.38 & 2.96 \\
Unclean & $2.63^{\mathrm{c}}$ & $3.71^{\mathrm{b}}$ & $3.50^{\mathrm{bc}}$ & $2.79^{\mathrm{bc}}$ & $4.92^{\mathrm{a}}$ & $3.04^{\mathrm{bc}}$ \\
Sulfide & $2.04^{\mathrm{c}}$ & $3.21^{\mathrm{a}}$ & $2.38^{\mathrm{bc}}$ & $2.21^{\mathrm{c}}$ & $3.13^{\mathrm{ab}}$ & $2.71^{\mathrm{abc}}$ \\
Overall flavor & $6.17^{\mathrm{a}}$ & $5.38^{\mathrm{bc}}$ & $5.75^{\mathrm{ab}}$ & $6.38^{\mathrm{a}}$ & $4.83^{\mathrm{c}}$ & $5.79^{\mathrm{ab}}$ \\
Firmness & $5.13^{\mathrm{bc}}$ & $5.66^{\mathrm{ab}}$ & $5.25^{\mathrm{bc}}$ & $5.00^{\mathrm{c}}$ & $5.88^{\mathrm{a}}$ & $5.50^{\mathrm{abc}}$ \\
Pastiness & 2.79 & 2.54 & 2.46 & 2.75 & 2.75 & 2.63 \\
Mealiness & $2.67^{\mathrm{b}}$ & $3.08^{\mathrm{ab}}$ & $2.63^{\mathrm{b}}$ & $2.58^{\mathrm{b}}$ & $3.54^{\mathrm{a}}$ & $3.04^{\mathrm{ab}}$ \\
Crumbliness & $2.75^{\mathrm{bc}}$ & $3.46^{\mathrm{ab}}$ & $2.33^{\mathrm{c}}$ & $2.50^{\mathrm{c}}$ & $3.58^{\mathrm{a}}$ & $3.29^{\mathrm{ab}}$ \\
Curdiness & 2.96 & 3.08 & 2.58 & 3.04 & 2.79 & 2.79 \\
Shortness & $4.92^{\mathrm{b}}$ & $6.08^{\mathrm{a}}$ & $4.38^{\mathrm{b}}$ & $4.54^{\mathrm{b}}$ & $6.21^{\mathrm{a}}$ & $6.21^{\mathrm{a}}$ \\
Overall body and texture & $6.58^{\mathrm{a}}$ & $5.96^{\mathrm{b}}$ & $6.79^{\mathrm{a}}$ & $6.71^{\mathrm{a}}$ & $5.54^{\mathrm{b}}$ & $5.96^{\mathrm{b}}$ \\
Overall appearance & $7.92^{\mathrm{ab}}$ & $7.46^{\mathrm{b}}$ & $7.83^{\mathrm{ab}}$ & $8.00^{\mathrm{a}}$ & $7.58^{\mathrm{ab}}$ & $7.75^{\mathrm{ab}}$ \\
Overall acceptability & $6.79^{\mathrm{a}}$ & $6.0^{\mathrm{bc}}$ & $6.50^{\mathrm{ab}}$ & $6.71^{\mathrm{a}}$ & $5.38^{\mathrm{c}}$ & $6.38^{\mathrm{ab}}$ \\
\hline
\end{tabular}

${ }^{a-c}$ Means in a row with the same superscripts are not different.

${ }^{1}$ Single attributes scored as $1=$ none, $5=$ definite, 9 = pronounced; overall flavor, body and texture, appearance, and acceptability scored as $1=$ poor, $5=$ average, $9=$ excellent.

${ }^{2} \mathrm{PM}=$ cheese made from pasteurized milk; $\mathrm{RM}=$ cheese made from raw milk; $\mathrm{MFE}=$ cheese made from raw milk inoculated with Escherichia coli $\mathrm{K} 12$ + microfiltration (MF); MFELP = cheese made from raw milk inoculated with $E$. coli K12 + MF + lactoperoxidase system (LP) activation; RME = cheese made from raw milk inoculated with $E$. coli K12; RMELP = raw milk inoculated with $E$. coli $\mathrm{K} 12+\mathrm{LP}$ activation.

in the concentration of $12 \%$ TCA SN between the cheeses made from LP-activated milk and the cheeses made without it.

The measurement of SN in 12\% TCA is an estimate of secondary proteolysis in ripened cheeses. During secondary proteolysis, high and medium molecular weight peptides are hydrolyzed by starter and NSLAB enzymes to lower molecular weight peptides and amino acids that are soluble in $12 \%$ TCA solution (Kuchroo and Fox, 1982). It has been reported that the levels of $12 \%$ TCA SN were less in cheese made from pasteurized milk than in cheese made from raw milk (Lane and Hammer, 1935; Lau et al., 1991). This finding is consistent with our observations. The greater level of $12 \%$ TCA SN in RM, RME, and RMELP cheeses may be related to their greater NSLAB populations, which play a key role in the secondary proteolysis. It is interesting to observe that PM cheese showed a greater level of primary proteolysis but a lower level of secondary proteolysis compared with RM, RME, RMELP, MFE, and MFELP cheeses.

\section{Sensory Characteristics of Cheeses}

The sensory evaluation results of the cheeses at 60 and $120 \mathrm{~d}$ of ripening are given in Tables 3 and 4, respectively.

Flavor Characteristics. Sensory evaluation results of the cheeses at $60 \mathrm{~d}$ of ripening indicated that the cheeses did not differ in bitterness. Other attributes such as acid taste, unclean, sulfide, and overall flavor were significantly different $(P<0.05)$ among the treatments. For the cheeses at $120 \mathrm{~d}$ of ripening, sensory results showed no differences in acid and bitterness attributes, whereas unclean, sulfide, and overall flavor attributes were different $(P<0.05)$ among the treatments. In addition, at 60 and $120 \mathrm{~d}$ of ripening, RM and RME cheeses showed differences in unclean and sulfide attributes $(P<0.05)$ compared with PM cheese. The overall flavor scores were similar for PM and MFELP cheeses at $60 \mathrm{~d}$; and the overall flavor scores were similar for PM, MFELP, MFE, and RMELP cheeses at $120 \mathrm{~d}$.

Body and Texture Characteristics. Body and texture attributes of the cheeses at $60 \mathrm{~d}$ of ripening indicated that cheeses did not differ in curdiness and pastiness attributes. Other attributes such as firmness, mealiness, crumbliness, shortness, overall body and texture, and overall appearance were different $(P<$ $0.05)$ among the treatments. The cheeses at $120 \mathrm{~d}$ were similar in curdiness attribute, whereas firmness, pastiness, mealiness, crumbiness, shortness, overall body and texture, and overall appearance were different $(P$ $<0.05$ ) among the treatments. At 60 and $120 \mathrm{~d}$ of ripening, RM, RME, and RMELP cheeses showed differences in shortness attribute $(P<0.05)$ compared with PM and MFELP cheeses. The overall body and texture of PM, MFE, and MFELP cheeses at $60 \mathrm{~d}$ were different $(P<0.05)$ from that of RM, RME, and RMELP cheeses. The overall body and texture of PM, MFE, and MFELP cheeses at $120 \mathrm{~d}$ was different $(P<0.05)$ from that of RM and RME cheeses. The overall appear- 
Table 4. Sensory evaluation of the cheese samples at $120 \mathrm{~d}$

\begin{tabular}{lcccccc}
\hline & \multicolumn{5}{c}{ Treatment $^{2}$} \\
\cline { 2 - 6 } Attribute $^{1}$ & PM & RM & MFE & MFELP & RME & RMELP \\
\hline Acid & 6.42 & 6.29 & 5.71 & 5.88 & 6.29 & 5.83 \\
Bitter & 2.13 & 2.46 & 2.00 & 2.46 & 2.58 & 2.13 \\
Unclean & $2.29^{\mathrm{d}}$ & $4.17^{\mathrm{ab}}$ & $3.67^{\mathrm{ab}}$ & $2.71^{\mathrm{cd}}$ & $4.25^{\mathrm{a}}$ & $2.29^{\mathrm{bc}}$ \\
Sulfide & $1.50^{\mathrm{b}}$ & $2.00^{\mathrm{a}}$ & $1.50^{\mathrm{b}}$ & $1.79^{\mathrm{ab}}$ & $1.88^{\mathrm{a}}$ & $1.67^{\mathrm{ab}}$ \\
Overall flavor & $6.46^{\mathrm{a}}$ & $4.92^{\mathrm{b}}$ & $6.13^{\mathrm{a}}$ & $6.29^{\mathrm{a}}$ & $4.88^{\mathrm{b}}$ & $6.0^{\mathrm{a}}$ \\
Firmness & $4.79^{\mathrm{b}}$ & $5.54^{\mathrm{a}}$ & $5.08^{\mathrm{ab}}$ & $4.96^{\mathrm{ab}}$ & $5.46^{\mathrm{a}}$ & $5.25^{\mathrm{ab}}$ \\
Pastiness & $2.67^{\mathrm{a}}$ & $1.96^{\mathrm{bc}}$ & $1.79^{\mathrm{c}}$ & $2.79^{\mathrm{a}}$ & $2.29^{\mathrm{abc}}$ & $2.33^{\mathrm{ab}}$ \\
Mealiness & $2.08^{\mathrm{ab}}$ & $2.17^{\mathrm{ab}}$ & $1.83^{\mathrm{b}}$ & $2.08^{\mathrm{ab}}$ & $2.46^{\mathrm{a}}$ & $2.25^{\mathrm{ab}}$ \\
Crumbliness & $2.63^{\mathrm{a}}$ & $2.50^{\mathrm{a}}$ & $1.50^{\mathrm{b}}$ & $1.67^{\mathrm{b}}$ & $2.96^{\mathrm{a}}$ & $2.63^{\mathrm{a}}$ \\
Curdiness & 2.08 & 2.46 & 1.96 & 2.54 & 2.21 & 2.17 \\
Shortness & $5.46^{\mathrm{c}}$ & $6.46^{\mathrm{ab}}$ & $5.75^{\mathrm{bc}}$ & $5.38^{\mathrm{c}}$ & $6.71^{\mathrm{a}}$ & $6.08^{\mathrm{ab}}$ \\
Overall body and texture & $6.46^{\mathrm{a}}$ & $5.70^{\mathrm{b}}$ & $6.67^{\mathrm{a}}$ & $6.38^{\mathrm{a}}$ & $5.63^{\mathrm{b}}$ & $6.13^{\mathrm{ab}}$ \\
Overall appearance & $8.04^{\mathrm{ab}}$ & $7.67^{\mathrm{b}}$ & $8.17^{\mathrm{a}}$ & $8.04^{\mathrm{ab}}$ & $7.21^{\mathrm{c}}$ & $7.83^{\mathrm{ab}}$ \\
Overall acceptability & $6.58^{\mathrm{a}}$ & $5.13^{\mathrm{c}}$ & $6.0^{\mathrm{ab}}$ & $6.25^{\mathrm{ab}}$ & $4.92^{\mathrm{c}}$ & $5.92^{\mathrm{b}}$ \\
\hline
\end{tabular}

\footnotetext{
${ }^{\mathrm{a}-\mathrm{d}}$ Means in a row with the same superscripts are not different.

${ }^{1}$ Single attributes scored as $1=$ none, $5=$ definite, $9=$ pronounced; overall flavor, body and texture, appearance, and acceptability scored as $1=$ poor, $5=$ average, $9=$ excellent.

${ }^{2} \mathrm{PM}=$ cheese made from pasteurized milk; $\mathrm{RM}=$ cheese made from raw milk; $\mathrm{MFE}=$ cheese made from raw milk inoculated with Escherichia coli $\mathrm{K} 12$ + microfiltration (MF); MFELP = cheese made from raw milk inoculated with $E$. coli K12 + MF + lactoperoxidase system (LP) activation; RME = cheese made from raw milk inoculated with $E$. coli K12; RMELP = raw milk inoculated with $E$. coli $\mathrm{K} 12$ + LP activation.
}

ance of MFELP cheese at $60 \mathrm{~d}$ was different $(P<0.05)$ from that of RM cheese. The overall appearance of MFE cheese at $120 \mathrm{~d}$ was different $(P<0.05)$ compared with RM and RME cheeses. The overall sensory acceptability of the cheeses at $60 \mathrm{~d}$ showed that PM and MFELP cheeses were more acceptable $(P<0.05)$ than RM and RME cheeses. The overall sensory acceptability of the cheeses at $120 \mathrm{~d}$ showed that PM, MFE, and MFELP cheeses were more acceptable $(P<0.05)$ than $\mathrm{RM}$ and RME cheeses.

\section{CONCLUSIONS}

Undoubtedly, pasteurization of milk before cheese manufacture remains an effective technique in reducing the risks of foodborne illnesses from cheese consumption. Our results suggest that utilization of $\mathrm{MF}$ with or without LP could be a promising alternative technique to lower pathogenic E. coli populations in unpasteurized milk. However, E. coli K12 (surrogate for $E$. coli O157:H7) populations increased during the manufacture of Cheddar cheese for reasons unrelated to contamination. If reactivation of $E$. coli during cheese making could be prevented, MF with or without LP could be an effective technique in reducing the counts of $E$. coli in raw milk cheeses.

Although raw milk cheeses exhibited similar levels of primary proteolysis as MF cheeses with or without LP, raw milk cheeses showed greater levels of secondary proteolysis. However, cheeses made from MF with or without LP exhibited greater overall sensory accept- ability compared with raw milk cheeses. However, further research is required before MF and LP could be used as an alternative to pasteurization for commercial-scale production of raw milk cheeses.

\section{ACKNOWLEDGMENTS}

This study was funded by a USDA National Integrated Food Safety Initiative Grant. The authors thank Vikram Mistry and Himanshu Somni for helping in microfiltration processing. Special thanks go to Maria Moutsoglou and Rosemary Nyoka for helping with cheese manufacture and analyses.

\section{REFERENCES}

Association of Official Analytical Chemists. 2000. Official Methods of Analysis. 17th ed. AOAC, Gaithersburg, MD.

Atamer, M., C. Kocak, A. Cimer, S. Odabasi, B. Tamucay, and N. Yamaner. 1999. Some quality characteristics of Kasar cheese manufactured from milk preserved by activation of lactoperoxidase/thiocyanate/hydrogen peroxide (LP) system. Milchwissenschaft 54:553-556.

Atherton, H. V., and J. A. Newlander. 1977. Chemistry and Testing of Dairy Products. AVI Publ. Co. Inc., Westport, CT.

Bynum, D. G., and D. M. Barbano. 1985. Whole milk reverse osmosis retentates or Cheddar cheese manufacture: Chemical changes during aging. J. Dairy Sci. 68:1-10.

Christensen, T. M. I. E., A. M. Bech, and H. Werner. 1991. Methods for crude fractionation (extraction and precipitation) of nitrogen components in cheese. Bull. Int. Dairy Fed. No 261:4-9.

Codex Alimentarius Commission. 1991. Guidelines for the preservation of raw milk by use of the lactoperoxidase system (CAC/GL 13-1991). http://www.codexalimentarius.net/download/stan dards/29/CXG_013e.pdf Accessed Apr. 9, 2007.

Dairy Management Inc. 2001. Activity extended shelf life in fluid milk: Creating hurdles for spoilage factors. Innovation in Dairy, 
Dairy Industry Technology Review. October 2001. Dairy Management Inc., Chicago, IL.

De Wit, J. N., and A. C. M. Van Hooydonk. 1996. Structure, functions and applications of lactoperoxidase in natural antimicrobial systems. Neth. Milk Dairy J. 50:227-244.

FAO. 1999. Manual on the use of the LP system in milk handling and preservation. Food and Agriculture Organization of the United Nations (FAO), Rome, Italy.

Food and Drug Administration. 1994. Cheddar cheese, Section 133.113, Title 21, Food and Drug Code of Federal Regulations. US Department of Health Education and Welfare, Washington, DC.

Fox, P. F., and P. L. H. McSweeney. 1996. Proteolysis in cheese during ripening. Food Rev. Int. 12:457-509.

Grappin, R., and E. Beuvier. 1997. Possible implication of milk pasteurization on the manufacture and sensory quality of ripened cheese: A review. Bull. Int. Dairy Fed. No. 327:16-19.

International Dairy Federation. 1988. Code of practices for the preservation of raw milk by lactoperoxidase system. Bull. Int. Dairy Fed. No. 234:1-15.

Johnson, E. A., J. H. Nelson, and M. Johnson. 1990. Microbiological safety of cheese made from heated-treated milk, part III. Technology, discussion, recommendations, bibliography. J. Food Prot. 53:610-613.

Kosikowski, V. F., and V. V. Mistry. 1990. Microfiltration, ultrafiltration, and centrifugation separation and sterilization processes for improving milk and cheese quality. J. Dairy Sci. 73:1411-1419.

Kuchroo, C. N., and P. F. Fox. 1982. Fractionation of the watersoluble nitrogen from Cheddar cheese: chemical methods. Milchwissenschaft 37:331-335.

Kussendrager, K. D., and M. C. A. Hooijdonk. 2000. Lactoperoxidase: Physico-chemical properties, occurrence, mechanism of action and applications. Br. J. Nutr. 84(Suppl.1):S19-S25.

Lane, C. B., and B. W. Hammer. 1935. Bacteriology of cheese. I. Effect of pasteurizing the milk on the nitrogenous decomposition in Cheddar cheese. Res. Bull. No.183. Iowa Agric. Exp. Stn., Ames.

Lau, K. Y., D. M. Barbano, and R. R. Rasmussen. 1991. Influence of pasteurization of milk on protein breakdown in Cheddar cheese during ripening. J. Dairy Sci. 73:561-570.

Lochry, H. R., G. P. Sanders, J. P. Malkames Jr., and H. E. Walter. 1951. Making American Cheddar cheese of uniformly good quality from pasteurized milk. Pages 1-39 in Cir. No. 880. United States Department of Agriculture, Washington, DC.

Maubois, J. L. 1997. Current uses and future perspectives of MF technology in the dairy industry. Bull. Int. Dairy Fed. No. 320:37-40.

McSweeney, L. P., P. F. Fox, J. A. Lucey, K. N. Jordan, and T. M. Cogan. 1993. Contribution of the indigenous microflora to the maturation of Cheddar cheese. Int. Dairy J. 3:613-634.

Meershon, M. 1989. Nitrate free cheese making with Bactocatch. North Eur. Food Dairy J. 55:108-113.

Mistry, V. V. 2002. Membrane processing in cheese manufacture. Page 300-306 in Encyclopedia of Dairy Science. Vol. 3. Academic Press, London, UK.
Neocleous, M., D. M. Barbano, and M. A. Rudan. 2002. Impact of low concentration factor microfiltration on the composition and aging of Cheddar cheese. J. Dairy Sci. 85:2425-2437.

Opstal, V., F. C. Bagamboula, T. Theys, C. S. Vanmuysen, and W. C. Michiels. 2006. Inactivation of Escherichia coli and Shigella in acidic fruit and vegetable juice by peroxidase systems. J. Appl. Microbiol. 101:242-250.

Park, H. S., E. H. Marth, J. M. Goepfert, and N. F. Olson. 1970. The fate of Salmonella typhimurium in the manufacture and ripening of low-acid Cheddar cheese. J. Milk Food Technol. 33:280-284.

Pastorino, A. J., C. L. Hansen, and D. J. McMahon. 2003. Effect of salt on structure-function relationships of cheese. J. Dairy Sci. 86:60-69.

Peterson, S. D., and R. T. Marshall. 1990. Nonstarter lactobacilli in Cheddar cheese: A review. J. Dairy Sci. 73:1395-1410.

Pruitt, K. M., D. N. Kamau, K. Miller, B. Mansson-Rahemtulla, and F. Rahemtulla. 1990. Quantitative, standardized assays for determining the concentration of bovine lactoperoxidase, human salivary peroxide, and human myeloperoxidase. Anal. Biochem. 191:278-286.

Pruitt, K. M., and J. Tenovuo. 1982. Kinetics of hypothiocyanite production during peroxidase catalyzed oxidation of thiocyanate. Biochim. Biophys. Acta 704:204-214.

Reitsma, J. C., and D. R. Henning. 1996. Survival of enterohemorrhagic Escherichia coli O157:H7 during the manufacturing and curing of Cheddar cheese. J. Food Prot. 59:460-464.

Richardson, G. H. 1985. Page 173-182 in Standard Methods for the Examination of Dairy Products. 15th ed. Am. Publ. Health Assoc. Washington, DC.

Ryser, E. T., and E. H. Marth. 1987. Behavior of Listeria monocytogenes during the manufacture and ripening of Cheddar cheese. J. Food Prot. 50:7-13.

Saboya, V. L., and J. L. Maubois. 2000. Current developments of microfiltration technology in the dairy industry. Lait 80:541553.

Sarkar, S., and K. A. Misra. 1992. Utilization of milk preserved by LP system for manufacture of cultured milk products. Indian Dairyman 44:536-540.

SAS Institute. 1999. SAS User's Guide: Statistics. Version 8.0 ed. SAS Inst. Inc., Cary, NC.

Schroeder, C. L., F. W. Bodyfelt, C. J. Wyatt, and M. R. McDaniel. 1988. Reduction of sodium chloride in Cheddar cheese: Effect on sensory, microbiological, and chemical properties. J. Dairy Sci. 71:2010-2020.

Seifu, E., M. E. Buys, and F. E. Donkin. 2004. Quality aspects of Gouda cheese made from goat milk preserved by the lactoperoxidase system. Int. Dairy J. 14:581-589.

Sousa, M. J., Y. Ardö, and P. L. H. McSweeney. 2001. Advances in the study of proteolysis during cheese ripening. Int. Dairy J. 11:327-345.

Upreti, P., L. Metzger, and P. Buhlmann. 2004. Glass and polymeric membrane electrodes for the measurement of $\mathrm{pH}$ in milk and cheese. Talanta 63:139-148

Zall, R. R., J. H. Chen, and D. J. Dzurec. 1983. Effect of thiocyanatelactoperoxidase-hydrogen peroxide system and farm heat treatment on the manufacturing of cottage cheese and Cheddar cheese. Milchwissenschaft 38:203-206. 